\title{
PERKEMBANGAN GURU MATEMATIKA ERA 4.0
}

\author{
Hasia Marto \\ Badan Penelitian dan Pengembangan Tolitoli \\ E-mail: hasiamarto@ymail.com
}

\begin{abstract}
Abstrak: Artikel ini bertujuan mendeskripsikan pengembangan guru matematika era 4.0. yang makin kompetitif. Perkembangan dunia tengah memasuki era revolusi industri 4.0. dimana teknologi telah menjadi basis dalam kehidupan manusia. Peran guru matematika tidak dapat digantikan sepenuhnya oleh perkembangan teknologi. Dalam menghadapi era 4.0 guru dituntut profesional di bidangnya, pengembangan profesionalisme guru matematika di era 4.0 menuntut guru matematika memiliki kompetensi karakter, keterampilan dan literasi dalam menghadirkan pembelajaran yang variatif dan inovatif. Hal ini dapat dimaknai bahwa peran guru menjadi mentor, fasilitator, motivator, inspirator, pengembang imajinasi, kreativitas, nilai-nilai karakter, serta team work, dan empati sosial karena nilai-nilai itulah yang tidak dapat diajarkan oleh mesin. Beberapa solusi yang dapat dilakukan guru matematika era 4.0 antara lain, mampu menguasai dan memanfaatkan teknologi digital dalam pembelajaran.
\end{abstract}

Kata kunci: perkembangan, guru profesional, Era 4.0

\begin{abstract}
This article aims to describe the development of mathematics teachers in the 4.0 era. increasingly competitive. The development of the world is entering the era of the industrial revolution 4.0. where technology has become the basis in human life. The role of the mathematics teacher cannot be completely replaced by technological development. In facing the era of 4.0 teachers are required to be professional in their fields, the development of professionalism in mathematics teachers in diera 4.0 requires mathematics teachers to have the competence of character, skills and literacy in presenting varied and innovative learning. This can be interpreted, that the role of the teacher becomes a mentor, facilitator, motivator, inspirator, imagination developer, creativity, character values, as well as team work, and social empathy because those values cannot be taught by machines. Some solutions that can be done by mathematics teacher in 4.0 era include, being able to master and utilize digital technology in learning.
\end{abstract}

Key word: development, teacher, Profesional, era 4.0

Revolusi industri 4.0 memberi pengaruh yang besar di berbagai bidang, namun tidak memberi pengaruh yang signifikan bagi bidang pendidikan. Saat ini tengah memasuki era revolusi industri 4.0. dimana teknologi telah menjadi basis dalam kehidupan manusia. Segala hal menjadi tanpa batas dan tidak terbatas akibat perkembangan internet dan teknologi digital. Di era ini pendidikan menjadi yang utama dalam menciptakan Sumber Daya Manusia (SDM) yang berkualitas, oleh karena itu pendidikan menjadi salah satu prioritas pemerintah sebagai wadah pembentuk manusia Indonesia seutuhnya.

Kualitas pendidikan dapat terwujud, jika diikuti dengan kualitas tenaga pendidik yakni guru yang menjadi tuntutan diberbagai jenjang pendidikan, baik bagi institusi penghasil maupun institusi pengguna (sekolah). Guru harus memiliki kualifikasi akademik sesuai yang diamanatkan oleh Undang-Undang. Tugas guru kapanpun dan dimanapun semakin berat dalam menyiapkan lulusan yang berkualitas. (Edi Hendri, 2010).

Menyiapkan lulusan yang berkualitas dan mampu bersaing secara global, dan menguasai perkembangan teknologi merupakan hal yang penting untuk semua orang dan 
penting bagi masa depan suatu negara (Yusutria, 2017). Maka kesiapan Indonesia menghadapi tantangan pendidikan era revolusi industri 4.0 adalah dengan segera meningkatkan kemampuan dan keterampilan sumberdaya manusia melalui pendidikan (Syamsuar \& Reflianto, 2017). Dalam hal ini yang menjadi perhatian adalah meningkatkan kualitas guru dalam pembelajaran, tidak terkecuali guru matematika. Berdasarkan hasil study PISA yang diselenggarakan oleh OECD sebuah badan PBB yang bertujuan untuk mengetahui kemampuan literasi matematika siswa dengan fokus studi kemampuan siswa dalam mengidentifikasi dan memahami serta menggunakan dasar-dasar matematika yang diperlukan dalam kehidupan sehari-hari, Indonesia pada tahun 2012 menduduki peringkat 64 dari 65 negara di dunia (OECD, 2013). Didukung hasil studi PISA (Program for International Student Assesmant), 2015 menempatkan Indonesia pada urutan 69 dari 76 negara, sedangkan TIMSS menempatkan Indonesia pada urutan ke 36 dari 49 negara. Masalah yang dihadapi siswa dalam pembelajaran matematika, tidak terlepas dari profesionalisme guru.

Di era 4.0, pengembangan profesi guru diarahkan pada kualitas professional, penilaian kinerja secara obyektif, transparan dan akuntabilitas, serta termotifasi untuk meningkatkan kinerja dan prestasi (Kristiawan M \& Rahmat Nur, 2018). Dari uraian tersebut dapat dinyatakan bahwa dalam era revolusi industri 4.0 guru matematika juga mempersipakan diri untuk meningkatkan kualitas pembelajaran guna turut serta mencerdaskan bangsa.

Salah satu cara untuk mencerdaskan kehidupan bangsa adalah melalui pendidikan. Dalam Rapat Kerja Nasional 2018, Sri Mulyani mengemukakan "kemajuan suatu Negara untuk mengejar ketertinggalan sangat tergantung pada tiga faktor yakni pendidikan, kualitas institusi dan kesediaan infrastruktur" (Ristekdikti, 2018). Dari pernyataan tersebut, dapat pahami bahwa pendidikan menjadi pilar utama dalam kemajuan suatu Negara. Selain itu, pendidikan sangat penting untuk meningkatkan sumber daya manusia yang berkualitas. Dalam meningkatkan sumber daya manusia yang berkualitas dibutuhkan pula pendidikan yang berkualitas.

Dalam UU No. 20 Tahun 2003 mengatakan bahwa "Pendidikan adalah usaha sadar dan terencana untuk mewujudkan suasana belajar dan proses pembelajaran agar peserta didik secara aktif mengambangkan potensi dirinya untuk memiliki kekuatan spiritual keagamaan, pengendalian diri, kepribadian, kecerdasan, akhlak mulia, serta keterampilan yang diperlukan dirinya dan juga masyarakat". Adapun korelasi pendidikan dengan revolusi industri 4.0. adalah dunia pendidikan dituntut harus mengikuti perkembangan teknologi yang sedang berkembang pesat serta memanfaatkan teknologi informasi dan komunikasi sebagai fasilitas lebih dan serba canggih untuk memperlancar proses pembelajaran. Dalam pembelajaran matematika diharapkan melalui pemanfaatan teknologi informasi dan komunikasi pola pembelajaran dapat berubah dari berpusat pada guru (teacher centered) menjadi berpusat pada peserta didik (student centered) untuk semua mata pelajaran. Namun faktanya perkembangan guru matematika sampai saat ini banyak mengalami perubahan, apalagi dengan diberlakukannya kurikulum 2013. Untuk membentuk guru matematika yang professional merupakan salah satu kunci menghadapi era 4.0.

Sisi lain guru matematika yang professional harus ditunjang penghargaan yang sesuai, sehingga dapat menfokuskan diri pada peningkatan kualitas pelayanan yang diberikan guru. Hal tersebut sejalan dengan kriteria professional yang menyebutkan guru berhak mendapatkan imbalan yang layak, tidak hanya berupa hadiah materi, tetapi juga dalam bentuk penghargaan, pujian, dan rasa hormat, serta rasa segan yang diberikan oleh 
masyarakat umum. Namun demikian hal ini belumlah didapatkan oleh guru secara secara umum, lamanya guru mengajar bukanlah jaminan sudah professional dibidangnya. Guru profesional tidak ditentukan oleh lamanya mengajar namun ada beberapa indicator. Hasil penelitian Hasia (2019) menyimpulkan salah satu kompetensi profesional guru ditentukan dengan melakukan peningkatan kemampuan pembelajaran melalui penelitian tindakan kelas, namun kemampuan tersebut dikategorikan rendah. Gordon (Hasia, 2018) menjabarkan kompetensi yang wajib dimiliki guru terdiri dari: knowledge, understanding, skill, value, attitude, dan interest. Kompetensi tersebut dapat digolongkan menjadi kompetensi personal, sosial dan profesional.

Perkembangan guru matematika saat ini tidak terlepas dari kompetensi yang dimiliki, dari tahun ke tahun pemerintah telah melakukan berbagai upaya untuk meningkatkan profesionalisme guru. Untuk menghadapi era 4.0, guru matematika diharapkan mampu menguasai teknologi merupakan keharusan. Namun demikian, Edi Hendi (2010) menyatakan bahwa kemampuan guru matematika dalam menguasai teknologi informasi untuk komunikasi untuk mengembangkan diri dalam kategori cukup, artinya kompetensi profesionalisme guru masih rendah, berbeda dengan penanganan kompetensi paedagogik dan akademik kompetensi sosial dan kepribadian guru dan calon guru masih belum optimal. Dalam menghadapi era revolusi industri 4.0 kompetensi apa yang harus dimiliki guru matematika dalam meningkatkan kualitas pembelajaran.

\section{PEMBAHASAN}

Perkembangan teknologi saat ini pun tidak lepas dari pengaruh matematika karena perkembangan matematika dan teknologi saling berkaitan satu dengan yang lain. Perkembangan dalam struktur dan penalaran matematika sering dapat diterapkan pada berbagai bidang ilmu yang lain, khususnya dalam perkembangan teknologi. Sebaliknya, perkembangan teknologi pun turut mendorong perkembangan matematika. Sudrajat (2008) menyatakan bahwa perkembangan pesat di bidang teknologi informasi dan komunikasi dewasa ini dilandasi oleh perkembangan matematika di bidang teori bilangan, aljabar, analisis, teori peluang dan matematika diskrit. Karenanya, untuk menguasai dan menciptakan teknologi di masa depan diperlukan penguasaan matematika yang kuat sejak dini. Pengembangan guru matematika di era 4.0 menghadapi tantangan yang jauh lebih besar dari era sebelumnya, setiap guru matematika membutuhkan pengembangan dan perkembangan yang efektif yaitu menggunakan pendekatan 'bottom up', menekankan kolaborasi yang berorientasi pada kemampuan guru mengatasi setiap permasalahan yang dihadapi, merupakan program-program yang interaktif dan saling terkait, yang dilaksanakan secara kontinyu dan direncanakan secara sistematik dan komprehensif (Castetter, 1996) serta menekankan pada keefektifan pembelajaran. Engstrom \& Danielson (2006) mengatakan bahwa bahwa model pengembangan hendaknya berlandaskan pada konsep kepemimpinan guru dan menggunakan proses pembelajaran kooperatif yang otentik dan melekat pada pekerjaan guru sehari-hari. Selain itu, menurut Lieberman (1996) strategi-strategi pengembangan guru yang menekankan pembelajaran dalam konteks sekolah bermanfaat untuk menghilangkan perasaan terisolasi pada guru ketika ia belajar sesuatu di luar sekolah dan berusaha membawanya ke dalam sekolah.

Guru matematika pada era industri 4.0 ditantang untuk melakukan akselerasi terhadap perkembangan informasi dan komunikasi. Pembelajaran di kelas dan pengelolaan 
kelas, pada abad ini harus disesuaikan dengan standar kemajuan teknologi informasi dan komunikasi.

Menurut Susanto (2010), terdapat 7 tantangan guru di era industri 4.0, yaitu:

1) Teaching in multicultural society, mengajar di masyarakat yang memiliki beragam budaya dengan kompetensi multi bahasa.

2) Teaching for the construction of meaning, mengajar untuk mengkonstruksi makna (konsep).

3) Teaching for active learning, mengajar untuk pembelajaran aktif.

4) Teaching and technology, mengajar dan teknologi.

5) Teaching with new view about abilities, mengajar dengan pandangan baru mengenai kemampuan.

6) Teaching and choice, mengajar dan pilihan.

7) Teaching and accountability, mengajar dan akuntabilitas.

Lebih lanjut Yahya S, Erni Arniza, Kamarudin (2010) menambahkan tantangan guru lainnya di era industri 4.0 yaitu, pendidikan yang berfokus pada character building dan pendidikan yang peduli perubahan iklim. Sehingga paradigma pembelajaran baru bagi guru matematika dituntut penguasaan pembelajaran dimana-mana atau U-learning dengan memanfaatkan teknologi. Hal ini menunjukkan bahwa pola pembelajaran yang dilakukan guru matematika mulai diarahkan untuk dapat meningkatkan kualitasnya melalui proses kognitif dalam belajar.

Menurut Hendi Suhendi (2017), berdasarkan Teori Brunner mengungkapkan ada tiga macam proses kognitif dalam belajar. Pertama, proses perolehan informasi baru, melalui kegiatan membaca, mendengarkan penjelasan materi yang diajarkan oleh guru, mendengarkan audiovisual, dan lain-lain. Kedua, proses mentransformasikan informasi yang diterima, yakni bahwa pengetahuan yang diterima oleh peserta didik agar sesuai dengan kebutuhan. Pengetahuan yang diterima akan dianalisis, diproses, dan diubah menjadi sebuah konsep yang lebih nyata atau abstrak sehingga dapat dimanfaatkan dalam kehidupan sehari-hari. Ketiga, menguji relevansi dan ketepatan pengetahuan. Hal ini untuk membuktikan sejauh mana informasi yang telah diterima bermanfaat bagi peserta didik dalam kehidupan sehari-hari.

Secara konseptual, pengembangan guru matematika sebagai tenaga profesi harus memenuhi berbagai persyaratan kompetensi untuk menjalankan tugas dan kewenangannya secara profesional, kompetensi profesional yang ditunjukkan bukan hanya dilihat dari guru matematika yang telah memperoleh sertifikasi. Namun guru yang dapat menghadapi tantangan di era digital 4.0 saat ini adalah guru yang memiliki kompetensi profesional di kompetensi pedagogik, kompetensi kepribadian dan memiliki kompetensi sosial.

Pengembangan kompetensi profesional adalah kompetensi atau kemampuan yang berhubungan dengan penyelesaian tugas-tugas keguruan. Kompetensi ini merupakan kompetensi yang sangat penting, sebab langsung berhubungan dengan kinerja yang ditampilkan. Kompetensi profesional guru matematika sekurang-kurangnya meliputi:1) menguasai subtansi bidang studi dan metodologi keilmuannya, 2) menguasai struktur dan materi kurikulum bidang studi, 3) menguasai dan memanfaatkan teknologi informasi dan komunikasi dalam pembelajaran, 4) mengorganisasikan materi kurikulum bidang studi, 5) meningkatkan kualitas pembelajaran melalui penelitian tindakan kelas."

Kompetensi pedagogik yang harus dimiliki oleh guru matematika antara lain memahami karakteristik peserta didik dari aspek fisik, sosial, kultural, emosional, dan intelektual, memahami latar belakang keluarga dan masyarakat peserta didik dan 
kebutuhan belajar dalam konteks kebhinekaan budaya. Untuk kompetensi kepribadian guru matematika dapat dikembangkan dengan: menampilkan diri sebagai pribadi yang mantap, stabil, dewasa, arif dan berwibawa, menampilkan diri sebagai pribadi yang berakhlak mulia dan sebagai teladan bagi peserta didik dan masyarakat, memiliki sikap, perilaku, etika, tata cara berpakaian, dan bertutur bahasa yang baik, mampu mengevaluasi kinerja sendiri dan dapat mengembangkan diri secara berkelanjutan.

Kompetensi lain yang harus dikembangkan guru matematika dalam menghadapi era 4.0 adalah kompetensi sosial, guru paling sedikit dapat: 1) berkomunikasi secara efektif dan empatik dengan peserta didik, orang tua peserta didik, sesama pendidik, tenaga kependidikan dan masyarakat, 2) berkontribusi terhadap pengembangan pendidikan di sekolah dan masyarakat, 3) berkontribusi terhadap pengembangan pendidikan di tingkat lokal, regional, nasional dan global, 4) memanfaatkan teknologi informasi dan komunikasi (ICT) untuk berkomunikasi dan mengembangkan diri, 5) memiliki sikap, perilaku, etika, tata cara berpakaian dan bertutur bahasa yang baik.

Guru matematika yang profesional dalam mengahadapi era 4.0 yang telah selain memiliki kompetensi yang telah diuraikan di atas, juga terdapat ciri-ciri profesional lainnya, seperti: 1) memiliki wawasan holistik, 2) memiliki tanggung jawab sekolah dan masyarakat, 3) mampu mengatasi kesulitan belajar siswa, 4) memfasilitasi pengembangan potensi peserta didik, 5) memiliki kemampuan menguasai teori dan prinsip belajar serta pembelajaran, 6) merancang konsep pembelajaran yang melibatkan peserta didik dalam belajar, 7) melaksanakan pembelajaran yang mendidik, 8) membuat evaluasi proses dan hasil belajar pembelajaran, 9) menguasai teknologi, 10) menguasai bahasa asing.

Era 4.0 mengubah paradigma pendidikan, yang tidak terlepas dari peran guru, karena berbagai informasi terbaru disampaikan pada peserta didik, selain itu ada media lain yang membantu peserta didik, namun bukan berarti peran guru dapat digantikan. Dengan maraknya informasi dari media social yang diterima peserta didik tentang pembelajaran matematika saat ini, maka guru menjadi salah satu sumber informasi bukan lagi sumber satu-satunya, namun kehadiran guru dalam pendidikan masih tetap dan terus dibutuhkan bagi peserta didik sebagai manajer dan fasilitator sehingga peserta didik dapat belajar secara produktif.

Guru di era revolusi industri 4.0 dituntut dalam hal penguasaan teknologi dalam pembelajaran. Hasil penelitian Muhasim (2017) menunjukkan bahwa pemanfaatan teknologi oleh guru memberi energi positif bagi siswa. Energi tersebut menumbuhkan motivasi siswa dalam belajar, namun guru tetap mengantisipasi efek negatif yang ditimbulkan dari teknologi digital tersebut. Dengan demikian, guru matematika juga dituntut memanfaatkan teknologi guna menumbuhkan motivasi bagi siswa, secara umum di Indonesia penggunaan teknologi digital dari tahun ke tahun mengalami peningkatan yang sangat pesat, penggunaannya tidak hanya didominasi oleh anak usia sekolah namun juga oleh orang dewasa.

Dirilis dari tekno Kompas.com (2018) Pengguna tehnologi digital seperti Internet di Indonesia pada tahun 2016 sebanyak 132,7 juta orang dari jumlah penduduk Indonesia sebanyak 256,2 juta orang. Dari sejumlah itu, 80 persen diantaranya berusia remaja 15-19 tahun. Data survei yang dilakukan oleh Asosiasi Penyelenggara Jaringan Internet (APJII) ini juga mengungkapkan bahwa rata-rata pengakses Internet di Indonesia sebanyak 67,2 juta orang atau 50,7 persen mengakses melalui perangkat genggam dan komputer. Tercatat di pulau jawa terbesar sekitar 86,3 juta orang atau 65 persen dari angka total pengguna internet. Di Sulawesi - Papua sebesar $10 \%$ dari jumlah penduduk, pengguna yang paling rendah adalah daerah Jogyakarta $1.5 \%$ dari jumlah penduduknya. 
Berdasarkan data Indikator Makro Sosial Ekonomi provinsi Sulawesi Tengah, jumlah penduduk Sulawesi Tengah tahun 2019 sebanyak 3.054.023 juta orang, artinya yang menggunakan teknologi digital sebagai pengguna aktif sebanyak 305.402 orang, penduduk usia sekolah antara usia 10-19 tahun berjumlah 525.464 orang. Dengan demikian, jika kita cermati pengguna teknologi masih termasuk rendah, namun demikian guru sebagai fasilitator dalam pembelajaran harus memahami dari manfaat teknologi bagi perkembangan pembelajaran guna peningkatan kualitas dan mutu pendidikan.

Pengembangan guru matematika di era 4.0 menuntut peran guru semakin optimal, konsekuensinya jika guru tidak biasa mengikuti perkembangan alam dan zaman, maka guru akan semakin tertinggal, sehingga tidak mampu menjalankan peran dan profesinya dengan baik. Pengembangan guru matematika era 4.0 memiliki karakteristik yang spesifik, yaitu:

1. Memiliki keimanan yang baik dan pekerja keras;

2. Memanfaatkan teknologi sesuai dengan kebutuhan;

3. Profesional dalam mengemban tugas sesuai dengan profesi;

4. Mampu menganalisis dan menyelesaikan permasalahan yang dihadapi peserta didik;

5. Dapat diteladani oleh peserta didik dalam berperilaku, bersikap dan bermoral yang baik;

6. Memiliki keteladanan dalam berestetika;

7. Menumbuhkan prinsip bersaing dan bersanding sesama guru;

8. Mampu mengoptimalkan benda sekitar sebagai media pembelajaran.

Terkait dengan karakteristik di atas, sejalan dengan Muhammad Surya (2018) selaku ketua umum PGRI mengemukakan bahwa guru sulit bersaing dengan mesin, yang jauh lebih cerdas, lebih cepat dan lebih efektif dalam pencarian informasi dan pengetahuan. Karena itu para guru perlu mengubah cara mengajar dari yang bersifat tradisional menjadi pembelajaran multi-stimulan agar lebih menyenangkan dan menarik. Demikian juga peran guru berubah dari semula menjadi pemberi pengetahuan menjadi mentor, fasilitator, motivator, inspirator, pengembang imajinasi, kreativitas, nilai-nilai karakter, serta team work, dan empati sosial karena nilai-nilai itulah yang tidak dapat diajarkan oleh mesin.

Merespon tantangan di era industri 4.0 ini, pemerintah menginisiasi lahirnya Smart Learning and Character Center yang merupakan pusat pengembangan dan peningkatan kompetensi pofesional dan pengembangan karakter guru sesuai kebutuhan zamannya. Agar guru matematika dapat berperilaku secara professional dalam menjalankan tugas dan profesinya, maka ada beberapa faktor yang perlu diperhatikan, yaitu: 1) keinginan untuk mewujudkan kinerja ideal, 2) memelihara citra profesi sebagai guru matematika, 3) memiliki keinginan untuk mengejar kesempatan-kesempatan profesionalisme, 4) sikap mental selalu ingin mengejar kualitas cita-cita profesi, dan 5) mental yang mempunyai kebanggaan profesi sebagai guru matematika. Perkembangan profesioalisme guru era 4.0 akan berkembang dalam menjalankan profesinya didasarkan pada panggilan jiwa. Selain itu, guru juga harus mampu melakukan penilaian secara komprehensif, Penilaian tidak hanya bertumpu pada aspek kognitif atau pengetahuan saja. Namun penilaian yang dilakukan oleh guru di era sekarang harus mampu mengakomodasi keunikan dan keunggulan para siswa, sehingga para siswa sudah mengetahui segala potensi dirinya sejak di bangku sekolah. Oleh karena itu, instrumen penilaian yang didesain guru matematika dapat menggali semua aspek yang menyangkut siswa, baik pengetahuan, keterampilan dan 
karakter. Aspek tersebut harus tergali, terasah dan terevaluasi selama proses pembelajaran di kelas, guna penyusunan laporan hasil pembelajaran. Mengahadapi era revolusi industri 4.0, guru dituntut memiliki kompetensi abad 21 yaitu memiliki kompetensi:

1) Karakter. Karakter yang dimaksud dalam kompetensi abad 21 terdiri dari karakter yang bersifat akhlak (jujur, amanah, sopan santun, dan lain-lain) dan karakter kinerja (kerja keras, tanggung jawab, disiplin, gigih, dan lain-lain). Dalam jiwa dan keseharian seorang guru era 4.0 sangat penting tertanam karakter akhlak. Dengan karakter akhlak ini seorang guru akan menjadi role model bagi semua siswanya. Pembelajaran dengan keteladan dari seorang guru akan lebih bermakna untuk para siswa. Karakter akhlak harus didukung dengan karakter kinerja dalam menunjang setiap aktivitas dan kegiatan yang dilakukannya, baik ketika pembelajaran di kelas maupun aktivitas lainnya.

2) Keterampilan yang perlu dimiliki oleh guru masa kini untuk menghadapi peserta didik abad 21 antara lain kritis, kreatif, kolaboratif dan komunikatif. Keterampilanketerampilan tersebut penting dimiliki oleh guru, agar proses pendidikan yang berlangsung mampu menghantarkan dan mendorong para siswa untuk menjadi generasi yang siap menghadapi tantangan perubahan zaman.

3) Literasi ditujukan agar guru melek dalam berbagai bidang. Setidaknya mampu menguasai literasi dasar seperti literasi finansial, literasi digital, literasi sains, literasi kewarnegaraan dan kebudayaan. Kemampuan literasi dasar ini menjadi modal bagi para guru untuk menghadirkan pembelajaran yang lebih variatif, tidak monoton hanya bertumpu pada satu metode pembelajaran yang bisa saja membuat para siswa tidak berkembang.

4) Menyajikan modul sesuai passion siswa. Di era perkembangan teknologi yang semakin berkembang, modul yang digunakan dalam pembelajaran tidak selalu menggunakan modul konvensional seperti modul berbasis paper. Guru matematika harus mampu menyajikan materi pelajaran dalam bentuk modul yang bisa diakses secara online oleh para siswa. Sudah banyak fitur yang bisa dijadikan oleh guru sebagai sarana untuk mengembangkan modul berbasis online. Namun demikian ketersediaan fitur untuk modul online ini harus dibarengi dengan kemampuan guru dalam mengemas fitur-fitur tersebut. Kombinasi antara pembelajaran tatap muka di kelas (konvensional) dan pembelajaran online ini dikenal dengan istilah blended learning. Kemampuan menggunakan digital elektronik menjadi keharusan dagi guru.

5) Melakukan Autentic Learning yang Inovatif. Sekolah bukan tempat isolasi para siswa dari dunia luar, justru sekolah adalah jendela untuk membuka dunia sehingga para siswa mengenali dunia. Untuk menjadikan sekolah sebagai jendela dunia bagi para siswa, guru harus memiliki kompetensi penyajian pembelajaran yang inovatif. Pembelajaran yang disajikan harus mengarah pada pembelajaran yang joyfull and inovatif learning, yakni pembelajaran yang memadukan hands on and mind on, problem based leraning dan project based learning. Dengan pengemasan pembelajaran yang joyfull and inovatif learning akan menjadikan siswa lebih terlatih dan terasah dalam semua kemampuannya, sehingga diharapkan lebih siap dalam menghadapi perkembangan zaman.

Konsep pembelajaran tersebut sejalan dengan arahan menteri pendidikan nasional pada acara hari Guru Nasional 25 November 2019, untuk mengahadapi tantangan zaman, maka perlu ada gerakan guru penggerak yang harus merdeka membuat inovasi 
pembelajaran dengan menjadikan siswa sebagai fokus utama, dan merdeka belajar dimana siswa bebas melakukan inovasi dalam belajar secara mandiri dan kreatif. Karena itu dibutuhkan transformasi mendasar bagi guru matematika di negeri ini, dengan memberikan ruang kreatifitas bagi siswa dengan menggunakan metode belajar yang tidak hanya abstratik, namun lebih memandang pada persoalan nyata. Sehingga guru matematika di era 4.0 harus terus berkembang dimasa yang akan datang.

\section{KESIMPULAN}

Hakekatnya perkembangan guru dibutuhkan oleh setiap orang dan semua orang sangat mengharapkan kehadiran citra guru yang ideal dan profesional. Untuk itu, guru akan lebih tetap berperan sebagai pendidik sekaligus berperan sebagai manager atau fasilitator pendidikan, sehingga guru harus sanggup merencanakan, melaksanakan dan mengawasi sumber daya pendidikan agar peserta didik dapat belajar secara produktif. Peran guru matematika tidak dapat digantikan sepenuhnya oleh perkembangan teknologi. Dalam menghadapi era 4.0, guru dituntut profesional di bidangnya, pengembangan profesionalisme memiliki kompetensi karakter, keterampilan dan literasi dalam menghadirkan pembelajaran yang variatif dan inovatif. Hal ini dapat dimaknai, bahwa peran guru menjadi mentor, fasilitator, motivator, inspirator, pengembang imajinasi, kreativitas, nilai-nilai karakter, serta team work, dan empati sosial karena nilai-nilai itulah yang tidak dapat diajarkan oleh mesin

\section{DAFTAR PUSTAKA}

Barnett, B. G., O'Mahony, G. R. \& Matthews, R. J. (2004). Reflective practice:thecornerstone for school improvement. Moorabbin, Vic: Hawker Brownlow Education

Budi Murtiyasa, (2015), Tantangan Pembelajaran Matematika Era Global, https://publikasiilmiah.ums.ac.id/bitstream/handle/11617/6005/28_47\%20PROF\%2 0BUDI\%20M.pdf di akses 28 September 2019

Bartell, Carol A. (2005). Cultivating high-quality teaching through induction and mentoring. California: Corwin Press

Beare H. (2008), Creating the Future school. London. RouutledgeFalmer.

Fahdini Renni, dkk (2014) Identifikasi kopetensi guru sebagai cerminan profesionalisme tenaga pendidik di Kabupaten Sumedang, Jurnal Mimbar Sekolah Dasar. 1(1) 2014: $33-42$.

Hendri Edi. (2010). Guru berkualitas, professional dan cerdas emosi, jurnal saung Guru 1(2) 2010: 1-11

Hasia M. 2016, Pendekatan Holistic Dalam Pembelajaran Matematika, Refleksi: Makassar

Hendi, Suhendi (2017), Teori belajar Matematka menurut Brunner, Gagne, Thorndike, Skinner, Peaget. (Online). https:hendisuhendi2012.wordpress.com/2013/06/08teoribelajar-matematika-menurut-brummer-gagne-thondike-skinner-peaget/. Diakses 27 September 2019.

Hasanah Aan. (2010) Pengembangan Profesi Guru.Bandung, CV Pustaka Setia. 
Kristiawan M \& Rahmat Nur, 2018. Peningkatan profesionalisme guru melalui inovasi pembelajaran. Jurnal Iqra. 3 (2): 372-390

Mullis, I.V.S, and Martin, M.O. (ed), 2013, TIMSS 2015 Assesment Frameworks, Boston: TIMSS and PIRLS International Study Center and IEA.

Muhammad Surya (2018), Guru sebagai penggerak perubahan di era Revolusi Industri 4.0. (online) http://pgri.or.id/sambutan-ketua-umum-pengurus-besar-pgri-pada-upacarahari-ulang-tahun-ke-73-pgri-dan-hari-guru-nasional-tahun-2018/ di akses 29 September 2019.

Muhasim. 2017. PengaruhTehnologi Digital,Terhadap Motivasi Belajar Peserta Didik, Jurnal Studi Keislaman dan Ilmu Pendidikan.5(2): 53-77

Sarjanaku.2010.Tantangan Guru. (Online), (http://www.sarjanaku.com/2010/11/tantanganguru-sebagai-tenaga.html) (diakses 23 September 2019)

Sapriani.R (2019. Profesionalism guru PAUD melati terpadu dalam meningkatkan mutu pendidikan era revolusi industry 4.0.

Syamsuar \& Reflianto (2018). Pendidikan dan Tantangan pendidikan dan pembelajaran berbasis teknologi informasi di era revolusi industry 4.0. Jurnal Ilmiah Teknologi Pendidikan. 6 (2) 1-13.

Tribun.new.com, 2019. Pidato Hari Guru nasional: Merdeka Belajar dan Guru Penggerak. https://www.tribunnews.com/nasional/2019/11/25/nadiem-makarim-jelaskan-2poin-penting-dari-pidato-hari-guru-merdeka-belajar-dan-guru-penggerak. diakses 2 Desember 2019

Yusutria, (2017), Profesionalisme guru dalam meningkatkan sumber daya manusia, Jurnal Irqa, 2(1) 38-46

Yahya S, Erny Arniza Ahmad and Kamarularifin Abd Jalil. (2010). The definition and characteristics of ubiquitous learning: A discussion. International Journal of Education and Development using Information and Communication Technology. (IJEDICT), 2010, Vol. 6, Issue 1, pp. 117-127

.....[http://www.pikiran-rakyat.com/pendidikan/2016/06/18/peringkat- pendidikanindonesia-masih-rendah-372187]. (online) diakses 29 September 2019. 